\title{
Introduction for the 56th Rankine Lecture
}

\author{
DAVID W. HIGHT
}

The 56th Rankine Lecture of the British Geotechnical Association was given by Professor Richard Jardine at Imperial College, London, on 16 March 2016. The following introduction was given by Professor David Hight, Senior Consultant, Geotechnical Consulting Group.

My Lord, ladies and gentlemen, good evening.

It is a great pleasure for me to introduce the 56th Rankine Lecturer, my friend and colleague, Professor Richard Jardine. Richard was born in 1953 at Rifle Range Camp, Nairobi, Kenya, the son of an army major. He moved on to Hong Kong at the age of four where he spent the next 4 years before the family settled in Kent and Richard went to school in Sandwich. Recently on a flight to Buenos Aires, Richard explained to me that his father did not rise above the rank of major because of an altercation with an army general over a matter of principle. Like father like son, I thought, because Richard too is a man of principle, prepared to argue his case when it comes to societal concerns and technical principles.

After graduating from Imperial College in 1974, where I understand he spent much of his time putting across his humanitarian concerns in protest marches, Richard worked first for Halcrow, then the Southern Water Authority, and later Kent County Council, all during a geotechnically challenging time of construction on the Thames marshes. This involved work on the Thames tidal defences and major new highways, including the M20 as well as the Sandwich and Queenborough bypasses. In this period he interacted with Duncan Nicholson and with Arthur Marsland of the Building Research Establishment (BRE), with whom, I am told, he had some lively technical discussions. Here his interest in soft clay engineering was ignited. Richard was to go back to Queenborough and with Philip Smith produce their seminal work on soft clay behaviour.

Richard's expertise in soft clay engineering was later recognised by the Sumo Wrestling Association of Japan who tasked him to design the dohyo earth they needed to perform on in London when they came to display their bulk and skills. I would not have fancied his chances had his design been wrong.

Richard went back to Imperial College in 1979 to do the Masters in soil mechanics and stayed on to do research into the behaviour of offshore soils and offshore oil production platforms: gravity, piled and tension leg. We worked together with John Burland on the first tension leg platform at Hutton. During this spell, Richard developed his expertise in instrumentation in the laboratory and field and his burning desire to understand and measure the small-strain stiffness, yielding and strength of soils and their part in the behaviour of driven piles. A desire that has driven and continues to drive his research.

\footnotetext{
* Geotechnical Consulting Group, London, UK
}

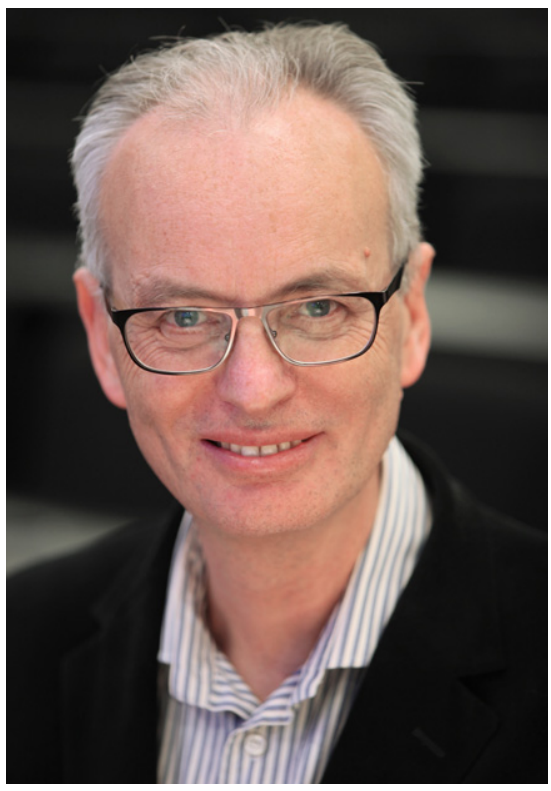

Professor Richard Jardine

Working with Andrew Bond, Barry Lehane and Fiona Chow, Richard used the results of meticulously made measurements on model piles installed in natural ground to unravel the complex stress changes around driven piles which control their capacity. This work led to the publication of the UK Marine Technology Directorate (MTD) and Imperial College pile (ICP) methods of pile design, which are used widely in practice today.

Richard became a lecturer at Imperial College in 1984, was appointed as Professor of Geomechanics in 1998 and progressed to hold the position of Consul of Engineering between 2012 and 2015 (which he resumed again in 2018). At Imperial College, Richard became a close friend of Professor Skempton, with whom he shared interests in history, music, art and of course soil mechanics.

Professor Jardine was elected a fellow of the Institution of Civil Engineers (ICE) in 2001, a fellow of the Royal Academy of Engineering in 2002, and a fellow of the City and Guilds Institute in 2008. In 2012 he was appointed as a Distinguished Overseas Scholar by the Chinese Ministry of Education.

Richard has supervised more than $20 \mathrm{PhD}$ students and it will be particularly gratifying for him to see so many of his past and present students, from as far afield as Australia, China and Japan, here tonight, together with his family.

Richard is much in demand as a consultant to major oil companies and developers of offshore wind farms, advising on the interpretation of ground conditions, on geohazards, including deepwater landslides, and on pile design and installation. Richard loves the challenge of new geotechnical problems, which he researches with enthusiasm and skill. 
He is particularly generous with his ideas and I am one of many who have benefited from this.

Richard has managed a number of large, international, joint industry research projects involving industrial partners and research groups in Europe and China, investigating subjects as diverse as pile ageing, cyclic loading and geotechnical problems in permafrost regions. Back at home, he continues his interest in the study of the mechanical properties of stiff clays and mudrocks in the UK and recently rekindled his interest in soft ground, working with Dutch colleagues on the raising of flood defences on peat. From mudrocks to peat sums up his range of interests and expertise in the behaviour of soils.

Reviewing Richard's list of 230 publications, which I am not going to recite, it is frightening to note that his output of high-quality refereed papers is accelerating. More awards will be added to the 17 already in the bag, such as the American Society for Testing and Materials (ASTM) Hogentogler Medal in 1993, the ICE Geotechnical Research Medals in 2007 and 2008, and the ICE Manby Prize in 2010. Professor Jardine was the first non-Japanese to be awarded their best paper prize for his work on kinematic yield surfaces and was recently made an honorary member of the Japanese Geotechnical Society. Two awards which stand out in the list are the Royal Academy of Engineering's Silver Medal in 1997 and Shell Exploration and Production's Technology and Innovation Award, also in 1997.

Major lectures are not new to Richard and recent ones include the Zheng lecture in China in 2008, the William Mong Lecture in Hong Kong in 2011, the International Society for Soil Mechanics and Geotechnical Engineering (ISSMGE) Bishop Lecture in Paris in 2013 and the American Society of Civil Engineers (ASCE) Sowers Lecture in Georgia in 2014. The one of which he is proudest, prior to tonight of course, was the Coulomb Lecture, which he was invited to give in Paris in 2006 and which he gave in French. Tonight I am told he will speak in English.

One thing I shall miss tonight is Richard's usual perceptive post mortem on the Rankine Lecture, in which he explains all the good points that I missed and the fallacies I have taken in. I am sure there will be plenty of the former and none of the latter tonight. His lecture will reflect those traits I referred to earlier, namely his societal concerns and technical principles, and will illustrate his many and varied areas of expertise.

On behalf of the British Geotechnical Association, I invite Professor Richard Jardine to deliver the 56th Rankine Lecture. 